\title{
Major Factors that Influencing Experiments of Chemistry Courses in Nekemte College of Teacher Education, Oromia Region, Ethiopia
}

\author{
Chali Abate Jote* \\ Department of Chemistry, Stream of Natural Sciences, Nekemte College of Teacher Education
}

Submission: January 15, 2019; Published: April 15, 2019

"Corresponding author: Chali Abate Jote, Department of Chemistry, Stream of Natural Sciences, Nekemte College of Teacher Education, Post Box No. 88, Nekemte, Ethiopia

\begin{abstract}
The purpose of this study was to examine the impact of the main factors, which affect the experiments of chemistry in Nekemte College of teacher education. To carry out the study a descriptive survey method was used. The sample consisted of 80 students, 5 instructors, 1 labtechnician and 5 college managements from the study area. Regarding the respondents, the students were randomly selected, while instructors, lab-technician and college managements were purposely selected. Data collection instruments used was questionnaires, interview and observation. Data obtained from questionnaires were analyzed using statistical tools like frequency and percentage. The data obtained from interview was analyzed qualitatively and data obtained from observation was analyzed quantitatively and qualitatively.

The results from the study showed that, factors that affect the experiments of chemistry in Nekemte college of teacher education were absence of well-trained lab-technician, unavailability of chemicals, equipment's and apparatus, lack of external and internal facilities, inappropriateness and irrelevance of manual, large number of students, shortage of instructional materials, inconvenient learning environment and etc. These problems undermine the quality of the experimentation in science education. Thus, the college and concerned bodies should address these problems jointly. Hence, the researcher forwarded based on the findings and conclusions, recommendations were made to alleviate the existing problems. Accordingly to minimize large number of students, hiring lab-technician and building alternative lab-rooms for each course, equipped with sufficient chemicals, apparatus, equipment's and instructional materials, preparing relevant and appropriate manual, allocating budgets for laboratory to purchase important materials and other which were assumed to solve the identified problems were recommended.
\end{abstract}

Keywords: Experiments; Laboratory; Chemicals; Apparatus; Laboratory technician

\section{Introduction}

For higher education the goal is to develop highly qualified, motivated and innovate human resources, produce and transfer advanced relevant knowledge for socio-economic development and poverty reduction with a view to turning Ethiopia into a middle-income country by the year 2017 [1]. Quality is also crucial challenge at higher education level due to the rapid expansion of this sub-sector. There is an increased need to focus on quality improvement with regard to human and material resources as well as reform of process [2].

Science has been thought by lecturing methods for a long time. In lecture method, the students listen to the teacher, but no any practically done. They learn concepts and theory. This affects their results of chemistry laboratory course as well as other natural science course [3]. In the same way natural science should be supported by experiment in addition to theoretical part. This makes the lesson clear and remembered by the student for a long period of time. As to Sharma [4] mentioned, it is important that experimental work must be a prominent feature in any natural science course and the primary objective in determining a techniques of instruction is to provide for a maximum of pupils performance, provide opportunity for the students, to check their ability to change theoretical learning in to practical and to discover new concept and extend their knowledge.

According to Yadav [5] no one is disputing that laboratory work should occupy central position in a programme of science education. Similarly, Sharma $[5,6]$ mentioned that, learning by doing is one of the major principles of teaching science. Experiment is also the way of teaching science which is useful to minimize the problems that students face in their learning process. In addition to this Kumar [7] indicated that most of the achievements of modern science are due to the application of experimental methods. Experiment is also the means by which students proof theoretical principles and facts they have thought in normal class. Kumar [6,7] also mentioned that practical laboratory is helpful on brooding 
pupils experience and develops initiative, resourcefulness and cooperation. We do not aim at stuffing the mind of the pupils with mere facts of science but at developing them the application of ability, skills of experimentation, improving scientific attitude, interests and appreciation. These can be achieved only if the students get the opportunities to work with themselves in a condition which pervades in science teaching $[4,6]$.

\section{Statement of The Problem}

To acquire scientific knowledge systematically in depth, the most important means is the teaching of science that should give an increased emphasis in enhancing student involvement in scientific investigation through laboratory work and field study. The emphasis arises from the view that science cannot be effectively learnt from books and lectures alone and neither can it taught by simply telling students about science. In order to learn science, one must do it. That is, a student must be involved in a real scientific investigation. Real scientific investigation does dual purposes. On one hand, it gives the student knowledge of the subjects and on the other; it provides the learner some understanding of scientific processes [8]. Therefore, if science studies are to progress, the college should be supported by laboratory which contain adequate facilities and materials. So, a major factor that influencing experiments of chemistry in Nekemte College of Teacher Education has not been studied as far as the knowledge of the researcher is concerned. This study is, thus, aimed at the major factors influencing the experiments of chemistry in Nekemte College of Teacher Education, Oromia Region, Ethiopia.

Accordingly, the study is designed to respond to the following basic questions.

1. What are factors that related to the implementation of conducting experiments?

2. Are there enough materials for the conduction of the experiments?

3. What is the student's, Instructor's and laboratory technician attitudes look like towards the laboratory experiments?

\section{Objectives}

The major purpose of the study is over viewing an investigation of major factors that hinder practical work of Chemistry in Nekemte College of Teacher Education. The specific objectives of the study are:

1. To assess factors that hinder to conduct laboratory experiments in the Nekemte College of Teacher Education.

2. To identify whether enough materials present or not for the conduction of the experiment.

3. To find out the relationships among Instructors, laboratory technician and students during laboratory session.

\section{Significant}

It is obvious that, research is important for various reasons. It gives a chance either for development or for improvement of a given country. Hence, the study becomes useful and timely in considering the problems of laboratory education. More and more students are recently coming to college ever year. However, the necessary laboratory educational inputs and materials are not at required level. The principal aim of this study is therefore, to identify the major factors that affects implementation of chemistry laboratory education in Nekmte College of Teacher Education. Therefore, the problems discussed in the study have the following importance.

1. The study is expected to contribute in the identification of chemistry laboratory materials in the Nekemte College of Teacher Education.

2. It is intended to create awareness to the problem among chemistry instructors in particular and among students and Science instructors at large.

3. It encourages college management to purchase laboratory materials.

4. It is also hoped that it will encourage others to do more and detailed research on the problem.

\section{Delimitation}

The study was concentrated only on major factors that influencing experiments of Chemistry in Nekemte College of Teacher Education. Due to time and resource limitation and in order to make the study manageable, its scope was geographically delimited to only Nekemte College of Teacher Education. Furthermore, the aspects were delimited to the attitude of chemistry department students and instructors related factors.

\section{Literature Review}

Sciences have been taught by lecturing methods and experiments. In lecture method, the students listen to the lesson, write down notes on their note books but they don't observe and hand what they learned in lecture class room. They learn concepts, facts and theory without practical work. This cast shade on the quality of knowledge acquired by the students [9]. In other cases, science subjects like chemistry, Biology and Physics should be taught with the aid of experiment in which the students observe, demonstrate and do some practical work in the laboratory, they have to relate what they learned in lecture class room with what they did, observed and demonstrated in the laboratory. This simplifies their understanding and teaching of science. As Sharma [6] point out it is, therefore, important that practical work should form a p8rominent feature in any science course and the primary objectives in determining a techniques of instruction is to provide for a maximum of pupils, practical activity (give) provide opportunity for the students to check, test and discover new concept and extend their knowledge. It also helps them to explore their world or environment $[10,11]$. 
Chemistry is essentially a practical oriented subject. No course in chemistry can be considered complete without including some practical work in it. For proper understanding of chemistry, it should be thought using many demonstration experiments. For carrying out demonstration experiments and for the performance of practical by the students, a chemistry laboratory is a must for every school offering chemistry as a subject [5]. However, as Kumar [7] stated that a special science room set aside for science faculties and materials is very desirable to an elementary school even where a self-contained program is conducted. Beside classroom, students' desk and chair, particular class-room is needed to do experiment and for demonstration and project work.

According to Solomon and Negusse [12] the general purpose of chemical experiment should be to give students some experience in using chemical knowledge, like other physical science, chemistry needs some experimental work at all level of educational institution which provides chemistry as independent subject including primary and secondary schools. Basically, it is chemical science. The students should be able to do chemistry experiments, handle chemicals and apparatus, known procedures of specific experiment, observe analysis and interpret what is done and observed during practical work. So that teaching chemistry without experiment is hazards or is not successful. The objectives of teaching in the school can only achieved when theoretical aspect of the subject is supported with practical activities in the laboratory room. To do experiments or to show practical work for the students, there must be chemistry laboratory room in the school.

As Kumer [7] also cited for carrying out demonstration of experiments and for the performance of practical by the students, chemistry laboratory is a must for every school offering chemistry as a separate subject. If there is no chemistry laboratory room in the school, it is possible to use some mechanism to solve the problem such as Converting/ improvising/class rooms, parts of the corridors and even shady corner for effective laboratory work, individual and small group investigation can also organized) sharing of costly equipment among schools in the neighbourhood [13]. Laboratory experiments are characteristic features of science of teaching at all levels of education. They served as indispensable parts (components) in this regard since origin of the use of laboratory methods in science teaching long time ago [14]. Nowadays, it is rare to find any science course without a substantial component of laboratory activity in teaching institutions. During such laboratory experiments, students are provided with specimens or work guide (manual) and some sort of equipment's which help them to investigate scientific problems in order to understanding theories and principles of science subjects $[13,14]$.

Many science educators (experts) suggested numerous benefits of science laboratory activities to students [15]. Some of these benefits include increasing students' interest and abilities in science subjects as well as their achievement in science [16]. Demonstrations, by instructors, can also be used as an option to support theories and lectures given in class rooms without adequate facilities to let students do the experiments by themselves [17]. However, as stated by Tobin [18] and other authors, meaningful learning is possible from a given laboratory experiments if the students are given ample opportunities to operate equipment's and materials that help them to construct their knowledge of phenomena and related scientific concepts.

There are reports that emphasize teaching a science with the help of laboratory experiments to be more enjoyable and stimulating to students than teaching the same subject matter only through lecture [19]. Use of laboratories also helps students to develop a positive attitude towards scientific research [20]. Being one of the science subjects, Chemistry is being taught in all countries of the world regardless of their level development. It is offered to students of high school, college and university levels [19]. Like other science subjects, teaching chemistry is also supported by laboratory experiments or practical sessions [21]. The original reason for development of chemistry laboratories was the need to produce skilled technicians for industry and highly competent workers for research laboratories [22]. Nowadays, however, chemistry practical courses are given not only to chemistry students but also to students in different fields or disciplines that require specialized knowledge [23].

Chemistry practical classes (experiments) are believed to help students understanding theories and chemical principles which are difficult or abstract otherwise. Moreover, they offer several opportunities to students. Some of these opportunities include handling chemicals safety and with confidence, gain hands-on experience in using instruments and apparatus, develop scientific thinking and enthusiasm to chemistry, develop basic manipulative and problem solving skills, gain opportunities to students as investigators of the experimental work, identify chemical hazards and learn to assess and control risks associated with chemicals [24]. It is important to note that designing chemistry laboratory experiments by itself is nota enough condition to achieve the desire objectives. It must be relevant. That is, it must understandable by students of a given education level.

There are two extreme thoughts regarding the importance of chemistry laboratory experiments. The first one is that in traditional approaches, little opportunity is given to the student initiatives or circumstance. In this approach, all the laboratory procedures are carefully listed in the provided manual, and frequently the student is simply asked to fill in a well-planned report template. At the end of a laboratory session, students have no real opportunity of understanding or learning the process of "doing Chemistry". The second one is that a student is given an opportunity to engage in deep learning [25]. This would provide an opportunity in identifying the main objectives of the work and in planning and executing it, of identifying the conceptual and practical difficulties encountered, recording and discussing the results and observations and suggesting practical alterations 
and improvements. The latter, thus, could result in a significant positive impact on a students' ability to learn both the desired practical skills and the underlying theory.

\section{Methods}

\section{Study Design}

The main purpose of the study was to assess the major factors that influencing experiments of chemistry in Nekmte College of Teacher Education. Descriptive survey research method was employed for this study as it helps to gather a variety of data related to a problem under the study. Therefore, to have a clear

\section{Sampling Techniques}

Table 1: Sample population of the study.

\begin{tabular}{|c|c|c|c|}
\hline No & Item & Population & 5 \\
\hline 1 & Chemistry Instructors & 5 & 800 \\
\hline 2 & $3^{\text {rd }}$ and 4 ${ }^{\text {th }}$ year Natural Science (Generalist \& Integrated) students & 80 \\
\hline 3 & Lab-technician & 1 & 5 \\
\hline 4 & College Management & 5 & 5 \\
\hline
\end{tabular}

The sample population of the study was obtained from Nekemte College of Teacher Education. Chemistry instructors, 3rd and 4th year Natural Science (Generalist \& Integrated) students, Management of the College and laboratory technician were included in the study. This is shown here under the following in (Table 1).

Concerning the sampling techniques $3^{\text {rd }}$ and $4^{\text {th }}$ year Natural Science (Generalist \& Integrated) students was selected using simple random sampling. Because in simple random sampling every individual in the populations have the same chance of being selected for the sample. As to Kothari simple random sampling provides each items of the population equal chance of inclusion in the sample. Availability sampling would be employed to select Chemistry instructors, laboratory technician and College Management. Because, they are few and by virtue of the rich information they have about the study topic.

\section{Data Collection Instruments}

In order to achieve the objectives, the instruments used to collect data for the study were questionnaires, interview and observation.

\section{Questionnaires}

The questionnaires were delivered to gather information from the Chemistry instructors, laboratory technician and third- and fourth-year Natural Science students (Generalist \& Integrated). Two sets of questionnaires were prepared. The first one is for 3rd and 4th year Natural Science (Generalist \& Integrated) students and the second one is for chemistry instructors and lab- technician to get the right feedback. The questionnaires were focused on major factors that hindering experiments of Chemistry in Nekemte College of Teacher Education and the methods in which improvement can be made for performing Chemistry laboratory. picture on the existing problems and to accomplish the objectives stated earlier a descriptive survey becomes appropriate.

\section{Data Sources}

Data sources in this study were based on the information obtained from primary data sources. The primary data was collected from 3rd and 4th year Natural Science (Generalist \& Integrated) students, laboratory technician, Chemistry instructors and college managements in the study area. This primary data was obtained by using questionnaires, interviews and observation checklists.

\section{Interview}

For instance, interview was one of the major tools employed in this study. This method was employed in the study to acquire qualitative data about various components of the program and to complement and obtain relevant data that were not handled by questionnaires. Therefore, structured interview method was prepared to obtain information form college management to cross check the responses made by lab-technician, instructors and students through questionnaires.

\section{Observation}

Since the study focuses on major factors that influencing experiments of Chemistry in Nekemte College of Teacher Education, the observation was conducted while classroom lesson delivery in Chemistry Laboratory experiments and to check experimental room facilities.

\section{Procedure of Data Collection}

The questionnaire is initially developed in the view of the basic research question of the study. Before it is administered to respondents, a pre-test is carried out to ensure language clarity and appropriateness of the item contained in questionnaire and converted to mother tongue language (Afan Oromo) for the students only. Experts in the field are consulted and appropriate change is made depending on comments during the try out. At last, these questionnaires were explained to respondents to maximize return of questionnaires. In addition, interviews and observation were carried out by the researcher himself.

\section{Method of Data Analysis}

The method of data analysis was based on the type of instrument employed. In this study collected data were categorized as per their similarities and presented in table form. 


\section{Annals of Social Sciences \& Management studies}

In addition, frequency and percentage were used accordingly to analyse the data collected by questionnaires. Once the data is analysed, it interpret and discussed. Whereas data obtained from interview was transcribed and analysed to substantiate qualitative information. Data from observation were analysed to substantiate both qualitative information (in the case of centre of status) and quantitative (in the case class room delivery) information. Finally, the major findings of the study were reported and realistic and feasible recommendations.

\section{Result and Discussion}

Under this results and discussion, the data gathered through data collection instruments were presented and interpreted according to the following issues. These issues were deals with different cases that related to the factors that influencing experiments of chemistry in Nekemte College of Teacher Education

\section{Issue Related to Level of satisfaction}

As it disclosed in (Table 2), majority of the respondents; instructors / lab-technician (83.33\%) and students (85\%) of them were interested in performing experiments of chemistry, while about $16.67 \%$ of instructor/ lab-technician and $15 \%$ students were no interested. Due to poor facilities of lab (66.67\%), poor support from college (33.33\%), inadequacy of equipment's and chemicals, and there is no upgrading and modern in-service training on experimentation for the Instructor/ lab-technician (66.67\%), they were dissatisfied $(83.33 \%)$ in their regular jobs. This shows that, it has negative effect on them towards laboratory experimentation.

Table 2: Respondent's response about level of satisfaction.

\begin{tabular}{|c|c|c|c|c|c|c|}
\hline \multirow{3}{*}{ No } & \multirow{3}{*}{ Items } & \multirow{3}{*}{ Options/Alternatives } & \multicolumn{4}{|c|}{ Respondents } \\
\hline & & & \multicolumn{2}{|c|}{$\begin{array}{l}\text { Instructors/ } \\
\text { lab-technician }\end{array}$} & \multicolumn{2}{|c|}{ Students } \\
\hline & & & f & $\%$ & f & $\%$ \\
\hline \multirow{3}{*}{1} & \multirow{3}{*}{$\begin{array}{c}\text { Are you interested in conducting exper- } \\
\text { iments of chemistry? }\end{array}$} & Yes & 5 & 83.33 & 34 & 85 \\
\hline & & No & 1 & 16.67 & 6 & 15 \\
\hline & & Total & 6 & 100 & 80 & 100 \\
\hline \multirow{6}{*}{2} & \multirow{6}{*}{$\begin{array}{l}\text { How do you rate your satisfaction level } \\
\text { as instructors/ lab technician? }\end{array}$} & Strongly satisfied & - & - & - & - \\
\hline & & Satisfied & 1 & 16.67 & - & - \\
\hline & & Dissatisfied & 5 & 83.33 & - & - \\
\hline & & Strongly dissatisfied & - & - & - & - \\
\hline & & Undecided & - & - & - & - \\
\hline & & Total & 6 & 100 & - & - \\
\hline \multirow{5}{*}{3} & \multirow{5}{*}{$\begin{array}{l}\text { The reason why you dissatisfied work- } \\
\text { ing as instructor/ lab-technician? }\end{array}$} & Poor facilities in the lab-room/class & 4 & 66.67 & - & - \\
\hline & & Poor support from college & 2 & 33.33 & - & - \\
\hline & & Low monthly salary & - & - & - & - \\
\hline & & Other & - & - & - & - \\
\hline & & Total & 6 & 100 & - & - \\
\hline \multirow{4}{*}{4} & \multirow{4}{*}{$\begin{array}{l}\text { How do you see in-service training } \\
\text { given on experiments? }\end{array}$} & Very satisfactory & - & - & - & - \\
\hline & & Satisfactory & 2 & 33.33 & - & - \\
\hline & & Not satisfactory & 4 & 66.67 & - & - \\
\hline & & Total & 6 & 100 & - & - \\
\hline
\end{tabular}

\section{Issue Related to Curriculum}

As it indicated in (Table 3), chemistry laboratory has specifically developed manual (100\%). The manual was prepared both by college instructors $(50 \%)$ and Oromia Regional
Educational Bureau (50\%). The prepared manual was not relevant to meet the curriculum, so it is medium (50\%) and low (50\%). The relevance of the manual with students learning module was medium (50\%) and low, it is about $33.33 \%$.

Table 3: Respondents response about curriculum issues.

\begin{tabular}{|c|c|c|c|c|}
\hline \multirow[t]{2}{*}{ No } & \multirow[t]{2}{*}{ Items } & \multirow[t]{2}{*}{ Options/alternatives } & \multicolumn{2}{|c|}{$\begin{array}{c}\text { Responses of lab-technician/ } \\
\text { instructors }\end{array}$} \\
\hline & & & $\mathbf{f}$ & $\%$ \\
\hline \multirow{3}{*}{1} & \multirow{3}{*}{ Does chemistry lab have specifically developed manual? } & Yes & 6 & 100 \\
\hline & & No & - & - \\
\hline & & Total & 6 & 100 \\
\hline
\end{tabular}


Annals of Social Sciences \& Management studies

\begin{tabular}{|c|c|c|c|c|}
\hline \multirow{5}{*}{2} & \multirow{5}{*}{ Who prepared the manual? } & REB & 3 & 50 \\
\hline & & The College & 3 & 50 \\
\hline & & REB only & - & - \\
\hline & & Others & - & - \\
\hline & & Total & 6 & 100 \\
\hline \multirow{4}{*}{3} & \multirow{4}{*}{$\begin{array}{l}\text { How do you rate the relevance of the manual in terms of meeting } \\
\text { the curriculum? }\end{array}$} & High & - & - \\
\hline & & Medium & 3 & 50 \\
\hline & & Low & 3 & 50 \\
\hline & & Total & 6 & 100 \\
\hline \multirow{4}{*}{4} & \multirow{4}{*}{$\begin{array}{l}\text { How do you rate the relevance of the manual with students' } \\
\text { module? }\end{array}$} & High & - & - \\
\hline & & Medium & 4 & 67.67 \\
\hline & & Low & 2 & 33.33 \\
\hline & & Total & 6 & 100 \\
\hline
\end{tabular}

\section{Issue Related to Teaching-learning Process}

As it asserted from (Table 4), all respondents replied that students preform laboratory work in a group of 7-9 students in one group (100\%). Thus, did not participate actively and all group members were not participating in lab-report writing $(50 \%)$. This indicates that the students have no interest to perform experiments because of the large number of students in a group as well as experiments are most of the time done by lab technician/ instructor as demonstration. This is because of the result of unavailability of materials and equipment's for each group in the lab room. The relationships among students, instructors and lab-technician were medium $(100 \%)$ in terms of facilitating and implementing the experiments. This due to no enough facilities in the lab room and the room was too small to help each group.

Table 4: Respondents' response's about teaching-learning process.

\begin{tabular}{|c|c|c|c|c|c|c|}
\hline \multirow{3}{*}{ No } & \multirow{3}{*}{ Items } & \multirow{3}{*}{ Options/alternatives } & \multicolumn{4}{|c|}{ Respondents } \\
\hline & & & \multicolumn{2}{|c|}{$\begin{array}{l}\text { Lab-technician / } \\
\text { instructors }\end{array}$} & \multicolumn{2}{|c|}{ Students } \\
\hline & & & f & $\%$ & f & $\%$ \\
\hline \multirow{4}{*}{1} & \multirow{4}{*}{$\begin{array}{l}\text { How do you organize your students while working laboratory? Or } \\
\text { how do you work laboratory? }\end{array}$} & Individually & - & - & - & - \\
\hline & & In pairs & - & - & - & - \\
\hline & & In group & 6 & 100 & 80 & 100 \\
\hline & & Total & 6 & 100 & 80 & 100 \\
\hline \multirow{5}{*}{2} & \multirow{5}{*}{ How many students are involved in one group? } & $4-5$ & - & - & - & - \\
\hline & & $7-9$ & 6 & 100 & 80 & 100 \\
\hline & & $10-13$ & - & - & - & - \\
\hline & & 14 and above & - & - & - & - \\
\hline & & Total & 6 & 100 & 80 & 100 \\
\hline \multirow{3}{*}{3} & \multirow{3}{*}{$\begin{array}{l}\text { Do you think that each group member participates while writing } \\
\text { lab-reports? }\end{array}$} & Yes & 3 & 50 & 40 & 50 \\
\hline & & No & 3 & 50 & 40 & 50 \\
\hline & & Total & 6 & 100 & 80 & 100 \\
\hline \multirow{4}{*}{4} & \multirow{4}{*}{$\begin{array}{l}\text { How do you rate the relationship among instructors, lab-technician } \\
\text { and students in terms of facilitating and implementing experi- } \\
\text { ments in lab-class? }\end{array}$} & High & - & - & - & - \\
\hline & & Medium & 6 & 100 & 80 & 100 \\
\hline & & Low & - & - & - & - \\
\hline & & Total & 6 & 100 & 100 & 100 \\
\hline
\end{tabular}

\section{Issue Related to Teaching Load and Class Size}

As it indicated in (Table 5), the average ratio of lab-technician to students for one class was 1:50 (100\%). This due to the absence of other laboratory classes and enough trained technician. But as Yadav (1995) noted that in case of a large class, it is convenient to divide the class in a suitable number of smaller groups, experimental work. A practical work group in no case should have more than 20 students. Teaching load of instructors besides laboratory work was about $66.67 \%$ and $33.33 \%$. This means that majority of the instructors have class teaching of the theoretical parts beside the laboratory classes. So, the laboratory work was not effectively performed (80\%) due to the results of unavailability of instructional materials for experimentation and teaching load. 
Table 5: Respondent's responses about teaching load and class size.

\begin{tabular}{|c|c|c|c|c|}
\hline \multirow[t]{2}{*}{ No } & \multirow[t]{2}{*}{ Items } & \multirow{2}{*}{$\begin{array}{c}\text { Options/ } \\
\text { Alternatives }\end{array}$} & \multicolumn{2}{|c|}{$\begin{array}{l}\text { Responses of lab-technician/ } \\
\text { instructors }\end{array}$} \\
\hline & & & f & $\%$ \\
\hline \multirow{6}{*}{1} & \multirow{6}{*}{ What is the average ratio of lab-technician-students per lab-session? } & $1: 60$ & - & - \\
\hline & & $1: 50$ & 6 & 100 \\
\hline & & $1: 40$ & - & - \\
\hline & & $1: 30$ & - & - \\
\hline & & $1: 20$ & - & - \\
\hline & & Total & 6 & 100 \\
\hline \multirow{5}{*}{2} & \multirow{5}{*}{ How many periods do you teach/ conducting experimentsin a week? } & $<4$ & - & - \\
\hline & & $4-6$ & - & \\
\hline & & $6-8$ & 4 & 66.67 \\
\hline & & $>8$ & 2 & 33.33 \\
\hline & & Total & 6 & 100 \\
\hline \multirow{3}{*}{3} & \multirow{3}{*}{$\begin{array}{l}\text { Do you think the number of periods you are teach/conducting laboratory work is } \\
\text { effective? }\end{array}$} & Yes & 1 & 16.67 \\
\hline & & No & 5 & 83.33 \\
\hline & & Total & 6 & 100 \\
\hline
\end{tabular}

\section{Issue Related to Structural Organization of the Laboratory Room}

Table 6: Respondent's responses about the organizational structure of lab-room.

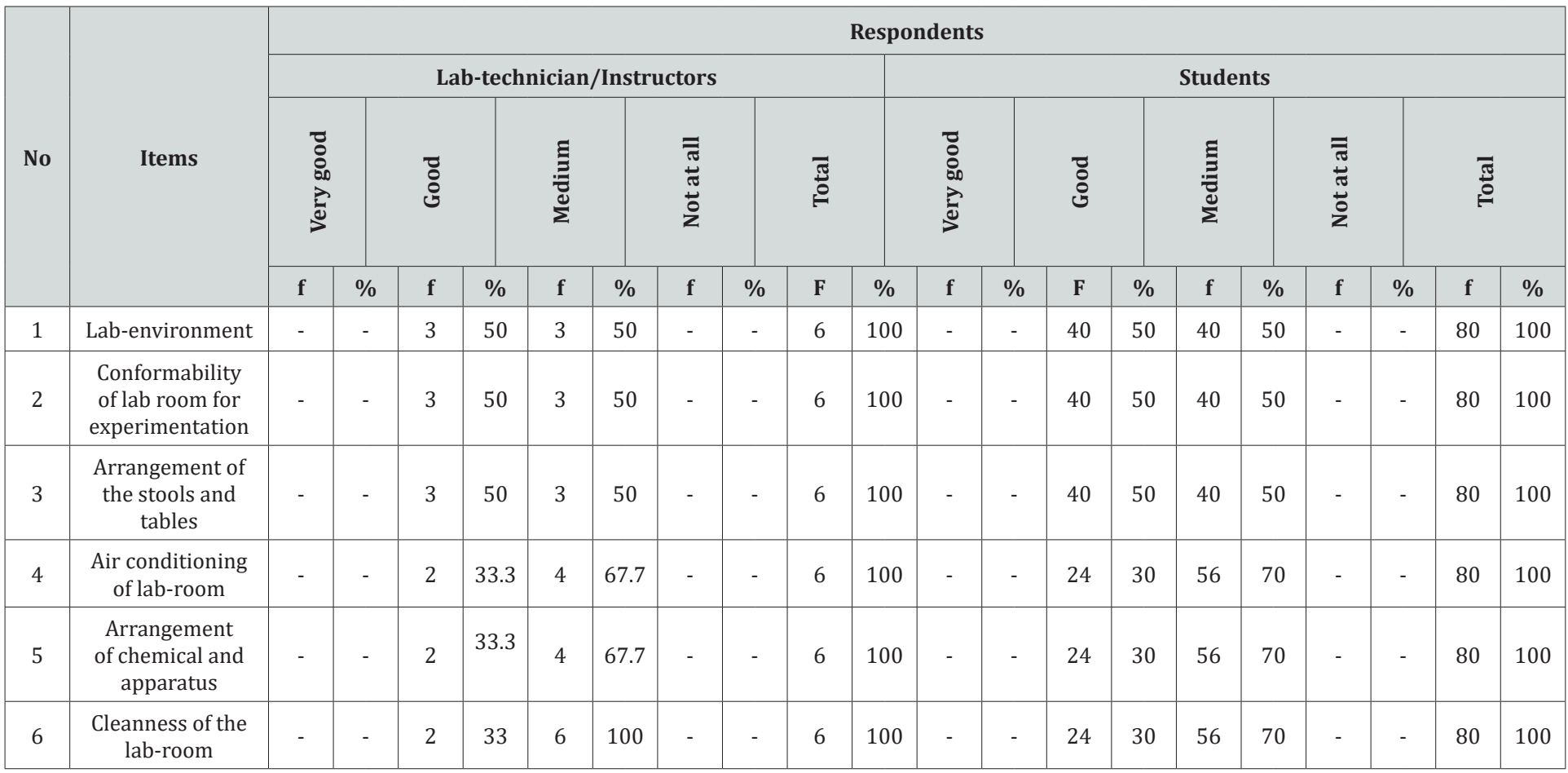

As it presented in (Table 6), respondents replied that, labenvironment, conformability of lab room for experimentation and arrangement of the stools and tables in lab were good (50\%) and medium (50\%). This is when we compare only with other natural science lab-class in our college. According to the data obtained through interview from Nekemte College of Teacher Education process owner of human resources replied that; Chemistry laboratory experiments room is not conducive enough for the practice/implementation of the lab-work. This is because of chemistry laboratory room lucks a lot of things to implement different experiments (April 25, 2017).

Lab-technician/ instructors replied about air conditioning of the lab room, arrangements of chemicals and apparatus and cleanness of the lab room were good (33.33\%) and medium $(67.7 \%)$ while students replied good (30\%) and medium (70\%). This because of the lab room was not build according to chemistry laboratory standard. 


\section{Issue Related to Availability of Instructional Materials of Laboratory}

Table 7: Respondent's responses about availability of instructional materials.

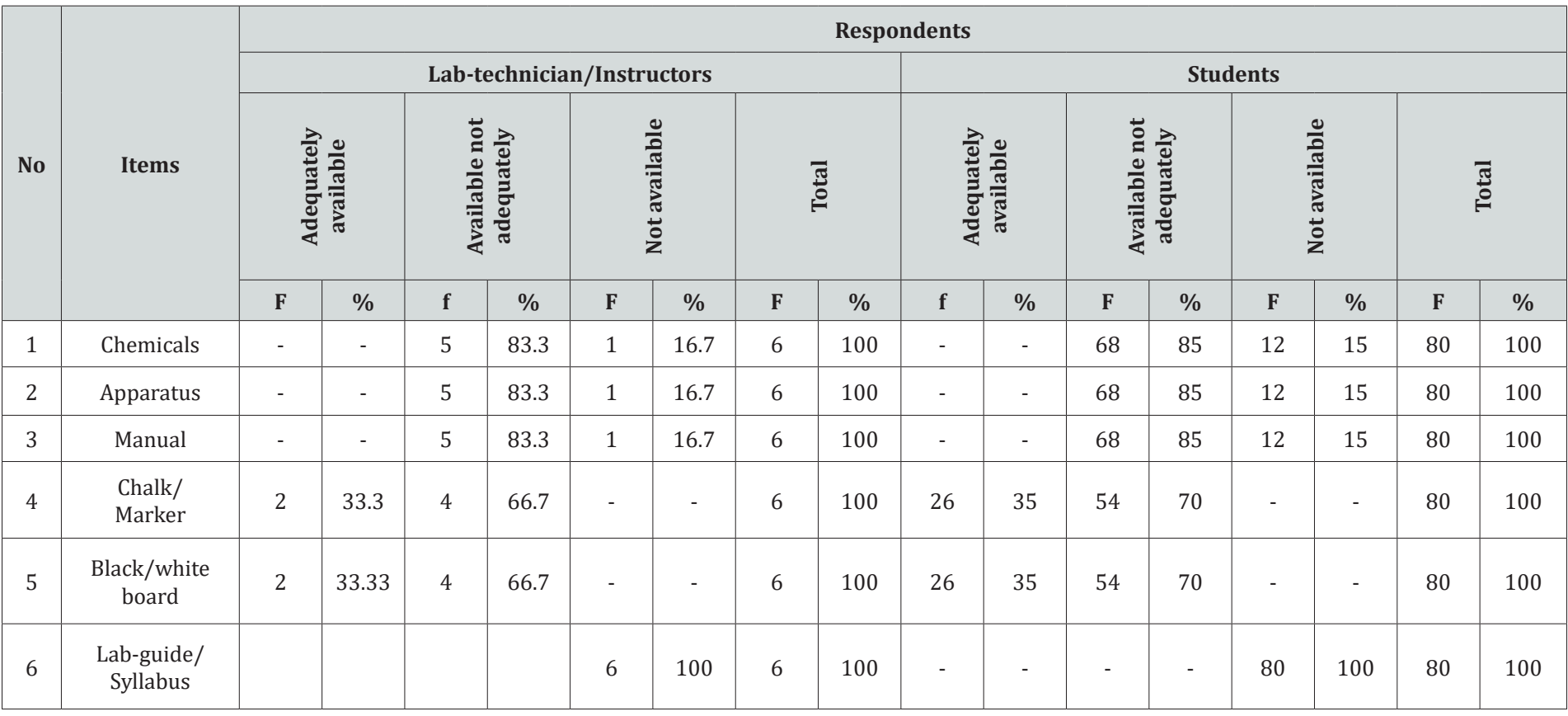

As replicated in (Table 7), all respondents replied that, instructional materials such as chalk/marker, black/white board were available not adequately (66.7\%), whereas chemicals, apparatus, manual, were inadequacies $(83.33 \%$ and $85 \%)$ and instructor lab-guide/syllabus was totally not available (100\%). This indicates that there were shortages of most of instructional materials for the experimentation. During the materials, the

\section{Issue Related to Internal Facilities of Chemistry Laboratory}

Table 8: Respondents responses about internal facility of chemistry laboratory.

\begin{tabular}{|c|c|c|c|c|c|c|c|c|c|c|c|c|c|c|c|c|c|}
\hline \multirow{4}{*}{ No } & \multirow{4}{*}{ Items } & \multicolumn{16}{|c|}{ Respondents } \\
\hline & & \multicolumn{8}{|c|}{ Lab-technician/Instructors } & \multicolumn{8}{|c|}{ Students } \\
\hline & & \multicolumn{2}{|c|}{$\begin{array}{l}\text { Adequately } \\
\text { available }\end{array}$} & \multicolumn{2}{|c|}{$\begin{array}{c}\text { Available } \\
\text { not ade- } \\
\text { quately }\end{array}$} & \multicolumn{2}{|c|}{$\begin{array}{l}\text { Not avail- } \\
\text { able }\end{array}$} & \multicolumn{2}{|c|}{ Total } & \multicolumn{2}{|c|}{$\begin{array}{l}\text { Adequately } \\
\text { available }\end{array}$} & \multicolumn{2}{|c|}{$\begin{array}{l}\text { Available not } \\
\text { adequately }\end{array}$} & \multicolumn{2}{|c|}{ Not available } & \multicolumn{2}{|c|}{ Total } \\
\hline & & f & $\%$ & f & $\%$ & f & $\%$ & f & $\%$ & f & $\%$ & f & $\%$ & f & $\%$ & f & $\%$ \\
\hline 1 & $\begin{array}{c}\text { Stools, tables, shelf and } \\
\text { drawers }\end{array}$ & 2 & 33.3 & 4 & 66.7 & - & - & 6 & 100 & 22 & 27.5 & 56 & 72.5 & - & - & 80 & 100 \\
\hline 2 & $\begin{array}{l}\text { Sink, wash basin, and } \\
\text { waste disposal }\end{array}$ & 2 & 33.3 & 4 & 66.7 & - & - & 6 & 100 & 22 & 27.5 & 56 & 72.5 & - & - & 80 & 100 \\
\hline 3 & $\begin{array}{c}\text { Storage of chemicals and } \\
\text { apparatus, water and gas } \\
\text { supplies }\end{array}$ & 2 & 33.3 & 4 & 66.7 & - & - & 6 & 100 & 22 & 27.5 & 56 & 72.5 & - & - & 80 & 100 \\
\hline 4 & $\begin{array}{c}\text { Dressing room Glove, } \\
\text { gown and fire extin- } \\
\text { guisher }\end{array}$ & - & - & - & & 6 & 100 & 6 & 100 & - & - & - & - & 80 & 100 & 80 & 100 \\
\hline 5 & $\begin{array}{l}\text { Fumi hood and first aid } \\
\text { box }\end{array}$ & - & - & - & - & 6 & 100 & 6 & 100 & - & - & - & - & 80 & 100 & 80 & 100 \\
\hline
\end{tabular}

As it shown in (Table 8), materials like stools and tables, water supplies, gas supplies, shelf and drawers, wash basin and sink, waste disposal, storage of chemicals and apparatus were available

(66.7\% and 72.5\%) as instructor/lab-technician and students replied respectively, but not adequately. Glove and gown, dressing room, fire extinguisher, hood and first aid box were not totally 


\section{Annals of Social Sciences \& Management studies}

available (100\%). Regarding this, one of the college management responded generally, about the internal facilities of chemistry labroom as:

It is fair in order to perform chemistry experiments but there is a shortage (scarcity) of different materials like apparatus for distilling water, fire extinguisher, chemicals, apparatus and other materials/equipment's for chemistry laboratory (May 8, 2017).

Furthermore, both the process owners of human resources and finance head of Nekemte College of Teacher Education also shared the same ideas. This indicates that there was inadequacy with all materials and shortage of such materials in the market.

\section{Issue Related to While Performing Laboratory}

As indicated in (Table 9), instructors /Lab-technician replied that time allotted for lab was somewhat enough (66.7\%) and they support and give feedback to their students was good (50\%) and medium (50\%), the way in which they gain the desired practical skills during performing laboratory was medium(100\%). And, students replied that time allotted for lab work was good (68\%), we get support and feedback (50\%) from instructors and labtechnician was good and understandably of each procedure in experimentation was medium (50\%). This shows that they are gaining desired practical skills in some extent.

Table 9: Respondents responses about performing laboratory.

\begin{tabular}{|c|c|c|c|c|c|c|c|c|c|c|c|c|c|c|c|c|c|c|c|c|c|}
\hline \multirow{4}{*}{ No } & \multirow{4}{*}{ Items } & \multicolumn{20}{|c|}{ Respondents } \\
\hline & & \multicolumn{10}{|c|}{ Instructor/Lab-technician } & \multicolumn{10}{|c|}{ Students } \\
\hline & & \multicolumn{2}{|c|}{ Very good } & \multicolumn{2}{|c|}{ Good } & \multicolumn{2}{|c|}{ Medium } & \multicolumn{2}{|c|}{ Not at all } & \multicolumn{2}{|c|}{ Total } & \multicolumn{2}{|c|}{ Very good } & \multicolumn{2}{|c|}{ Good } & \multicolumn{2}{|c|}{ Medium } & \multicolumn{3}{|c|}{ Not at all } & \multirow{2}{*}{\begin{tabular}{|} 
Total \\
\begin{tabular}{|r|}
$\%$ \\
\end{tabular}
\end{tabular}} \\
\hline & & f & $\%$ & f & $\%$ & f & $\%$ & f & $\%$ & f & $\%$ & f & $\%$ & $\mathbf{F}$ & $\%$ & f & $\%$ & f & $\%$ & f & \\
\hline 1 & $\begin{array}{l}\text { Time allotted for lab- } \\
\text { work }\end{array}$ & 4 & 66.7 & 2 & 33.3 & & & - & - & 6 & 100 & 54 & 68 & 26 & 32 & - & - & - & - & 80 & 100 \\
\hline 2 & $\begin{array}{l}\text { Support that students } \\
\text { get from Lab-techni- } \\
\text { cian/ instructor while } \\
\text { laboratory work }\end{array}$ & - & - & 3 & 50 & 3 & 50 & - & - & 6 & 100 & 26 & 32 & 54 & 68 & - & - & - & - & 80 & 100 \\
\hline 3 & $\begin{array}{l}\text { Understandably of } \\
\text { each procedure. }\end{array}$ & - & - & 3 & 50 & 3 & 50 & - & - & 6 & 100 & - & - & - & - & 80 & 100 & - & - & 80 & 100 \\
\hline 4 & $\begin{array}{l}\text { Feedback that } \\
\text { lab-technician / } \\
\text { instructor give for } \\
\text { students or feedback } \\
\text { students get. }\end{array}$ & - & - & 3 & 50 & 3 & 50 & - & - & 6 & 100 & & & 40 & 50 & 40 & 50 & & & 80 & 100 \\
\hline 5 & $\begin{array}{l}\text { Gaining desired prac- } \\
\text { tical skills by students. }\end{array}$ & - & - & - & - & 6 & 100 & - & - & 6 & 100 & & & & & 40 & 100 & & & 80 & 100 \\
\hline
\end{tabular}

\section{Issue Related to Importance of Laboratory}

Table 10: Respondent's responses about importance of laboratory.

\begin{tabular}{|c|c|c|c|c|c|c|}
\hline \multirow{3}{*}{ No } & \multirow{3}{*}{ Items } & \multirow{3}{*}{ Options/alternatives } & \multicolumn{4}{|c|}{ Respondents } \\
\hline & & & \multicolumn{2}{|c|}{ Instructors/Lab-technician } & \multicolumn{2}{|c|}{ Students } \\
\hline & & & $\mathbf{F}$ & $\%$ & f & $\%$ \\
\hline \multirow{6}{*}{1} & \multirow{6}{*}{ It provides theory with practical aspect. } & Strongly agree & 6 & 100 & 80 & 100 \\
\hline & & Agree & - & - & - & - \\
\hline & & Uncertain & - & - & - & - \\
\hline & & Disagree & - & - & & \\
\hline & & Strongly disagree & - & - & & \\
\hline & & Total & 6 & 100 & 80 & 100 \\
\hline \multirow{6}{*}{2} & \multirow{6}{*}{ Enables working in groups. } & Strongly agree & 6 & 100 & 80 & 100 \\
\hline & & Agree & & & & \\
\hline & & Uncertain & - & - & & \\
\hline & & Disagree & - & - & & \\
\hline & & Strongly disagree & - & - & & \\
\hline & & Total & 6 & 100 & 80 & 100 \\
\hline
\end{tabular}


Annals of Social Sciences \& Management studies

\begin{tabular}{|c|c|c|c|c|c|c|}
\hline \multirow{6}{*}{3} & \multirow{6}{*}{ An opportunity to engage deep learning } & Strongly agree & 6 & 100 & 80 & 100 \\
\hline & & Agree & - & - & - & - \\
\hline & & Uncertain & - & - & - & - \\
\hline & & Disagree & - & - & - & - \\
\hline & & Strongly disagree & - & - & - & - \\
\hline & & Total & 6 & 100 & 80 & 100 \\
\hline \multirow{6}{*}{4} & \multirow{6}{*}{ Understand theoretical and chemical principles } & Strongly agree & 6 & 100 & 80 & 100 \\
\hline & & Agree & & - & - & - \\
\hline & & Uncertain & - & - & - & - \\
\hline & & Disagree & - & - & - & - \\
\hline & & Strongly disagree & - & - & - & - \\
\hline & & Total & 6 & 100 & 80 & 100 \\
\hline \multirow{6}{*}{5} & \multirow{6}{*}{ Develop the skill of writing lab-reports. } & Strongly agree & 6 & 100 & 80 & 100 \\
\hline & & Agree & - & - & - & - \\
\hline & & Uncertain & - & - & - & - \\
\hline & & Disagree & - & - & - & - \\
\hline & & Strongly disagree & - & - & - & - \\
\hline & & Total & 6 & 100 & 80 & 100 \\
\hline \multirow{6}{*}{6} & \multirow{6}{*}{ Develop scientific skills } & Strongly agree & 6 & 100 & 80 & 100 \\
\hline & & Agree & - & - & - & - \\
\hline & & Uncertain & - & - & - & - \\
\hline & & Disagree & - & - & - & - \\
\hline & & Strongly disagree & - & - & - & - \\
\hline & & Total & 6 & 100 & 80 & 100 \\
\hline
\end{tabular}

As shown from (Table 10), all respondents (instructors, lab technician and students) were strongly agree (100\%) with the importance of laboratory work. Because of it provides theory with practical work, enables working in groups, an opportunity to engage deep learning, understand theoretical and chemical principles, develop the skills of lab reports and develop scientific skills.

\section{Challenging Factors that Affect the Implementation of Experiments}

The practices/implementation of any science experiment is affected negatively by internal factors such as absence of chemicals and apparatus, insufficient of equipment's, luck of enough time and well-trained manpower. Considering the major factors that influencing the experiments of chemistry in Nekemte College of Teacher Education many of the respondents on the comment section of questionnaires and interviews forwarded many varieties of factors associated with it.

a. Unavailability of conducive facilities such as apparatus for distilling water, dressing room, first aid, alternative labroom/class, fire extinguisher and separated toilet for boys and girls and etc.

b. Many of the chemistry instructors and lab-technician did not take in-service training which equips them with the necessary skills of performing experiments of chemistry in order to upgrade with modern chemistry practical work.

c. Lack of budget allotted for the practical work of chemistry laboratory.

d. Unavailability such materials in the market and complex nature bidding in order to purchasing the materials.

e. Large number of students in one laboratory class/room.

f. Lack of well-trained lab-technicians as the basic knowledge of the students.

g. Less basic knowledge of the students/trainees and less involvement of students in performing experiments and

h. While conducting chemistry laboratory less involvement of the students and all group members are not taken part in writing lab-report equally.

\section{Conclusion and Recommendation}

The result of the study suggested that the students, labtechnician and instructors were interest of performing the experiments very highly. But due to the facilities and organizational structure of the lab-room/class it is difficult to conduct experiments of chemistry. Discussion with the respondents and information gathered through different tools identified that experiments of 
chemistry are entangled with multiple problems. There were a serious shortage of apparatus, chemicals and other equipment's. These shortages were making experiments of chemistry inefficient and ineffective. Unavailability instructional materials such as manual, chalk/marker, black/white board, lab-guide/ syllabus were not as required level. This shortage leads to the experiment is not implemented as it intended in the curriculum. Many of the chemistry instructors and lab-technician had not equipped them with the necessary skills of performing experiments of chemistry in order to upgrade with modern chemistry experiments. This was due to the absence of in-service training provided to them and lack of facilities.

Based on the major finding of the study, the following recommendations are forwarded:

i. Nekemte College of Teacher Education should work on the availability, relevance and appropriateness laboratory manual with concerned bodies like Ministry of Education, nongovernmental organizations, Oromia Regional Educational Bureau and others college in the region.

ii. Nekemte College of Teacher Education should work in collaboration with Oromia Regional Educational Bureau to hire more qualified lab-technician as to overcome the existing problem.

iii. In Nekemte College of Teacher Education, there were high shortage of chemicals, apparatus and other facilities normally exist. An instructional material has been in a short supply. Therefore, the College in collaboration with Oromia Regional Educational Bureau is recommended to:

iv. Allocating the right budget for instructional materials and facilities to the chemistry laboratory.

v. Encourage private investors as well as non-governmental organizations to support the necessary chemicals and materials for the chemistry laboratory.

vi. The chemistry lab environments in the experimental work room/class have been found to be unconducive in terms of inadequacy of the resources like lab-class/room facilities, instructional materials, etc. Hence, the college with Oromia Regional Educational Bureau and other concerned bodies such as the non-governmental organizations, private sectors, should device mechanism to alleviate the problems such as developing minimum standard about experimental room construction and distribution of the required laboratory materials by Nekemte College of Teacher Education.

vii. The external and internal facilities should be fulfilled by the college to promote experiments and to encourage active learning methods that appreciable by students in experiments of chemistry.

viii. Nekemte College of Teacher Education in collaboration with Oromia Regional Educational Bureau should provide in-service training opportunities to lab-technician and instructors on experiments of modern chemistry.

ix. Nekemte College of Teacher Education should understand the importance of experiments in all-Natural Science and particularly in chemistry to equip the laboratory with all necessary instructional materials.

x. Enhancing the relationship among students, instructors and lab-technician by encouraging the students and by providing various incentives for the instructors and labtechnician to minimize the problem.

xi. Instructors and lab-technician should support their students during experimentation to promote self-learning, actively participate in experiments, the way they prepare flow chart and writing lab-report, care should be taken in the laboratory, teaching safety rules, identifying hazardous chemicals, promoting equal participation of male and female students and etc.

xii. Nekemte College of Teacher Education should equip the students, lab-technician and instructors with gown and glove and other materials and chemistry laboratory room should have first aid box and fire extinguisher to minimize risk that created while performing experiments of chemistry (Appendix).

\section{References}

1. MOE (2009) Action research in primary schools in Ethiopia (USAID). Addis Ababa, United printers PLC. Ethiopia.

2. MOE (2010) Education Sector Development Program II (ESDP II) (2002/03-2004/05). Addis Ababa: United printers PLC. Ethiopia.

3. Polles, JS (2006) PhD thesis. The Chemistry teaching laboratory: The student perspective. Purdue University, Indiana, USA.

4. Sharma, RA (2008) Fundamentals Educational Research. New Delhi, International publishing House. India.

5. Yadav, MS (1995) Teaching of Chemistry. Anmol Publication P.V.T. and LTD. India.

6. Sharma, RC (1998) Modern Science Teaching. Dhanpati Rai Publishing Company (P). LTD. India.

7. Kumar, A (1995) Teaching of Physical Science. Anmol Publications PVT. LTD. India.

8. Mekuanent Kelemu (1992) An evaluation of teaching of Biology in some selected secondary schools of Addis Ababa vis-à-vis an enquiry model (unpublished M. Sc Thesis). Addis Ababa, Ethiopia.

9. Reddy YUR (2001) Methodology of Teaching Natural Science, Teaching Methods, Teaching Aids and Laboratory Work in Natural Science. Educational Media Agency; Addis Ababa, Ethiopia.

10. Solomon Libsu, Negusie Negash (2001) Teaching Chemistry in Secondary School. 3(2): 27-34.

11. Vaidya, N (1971) The impact of Science Teaching. OXFORD \& IBH Publishing CO. PVT. LTD. New Delhi, India.

12. Fisher D, Harrison A, Henderson D, Holstein A (1998) Laboratory learning environments and practical tasks in senior secondary science classes. Res Sci Educ 28(3): 353-363. 


\section{Annals of Social Sciences \& Management studies}

13. Garnett PJ, Garnett PJ, Hacking MW (1995) Refocusing the Chemistry lab: A case for laboratory-based investigations. Australian Sci Teachers J 41: 26-32.

14. Pavesic BJ (2008) Science achievement, gender differences, and experimental work in classes in Slovenia as evident in TIMSS studies. Studies in Educ Evaluat 34(2): 94-104.

15. McKee E, Williamson VM, Ruebush LE (2007) Effects of a demonstration laboratory on student learning. J Sci Educ Technol 16: 395-400.

16. Tobin KG (1990) Research on science laboratory activities: In pursuit of better questions and answers to improve learning. School Sci Math 90: 403-418.

17. Hofstein A, Lunetta VN (2004) The laboratory in science education Foundation for 21st century. SCi Educ 88: 28-54.

18. Adams CS (1942) The importance of laboratory work in General chemistry at the college level. J Chem Educ 19: 266.

19. Thomson GW (1918) The importance of practical Chemistry. Ind Eng Chem 10: 829-830.
20. Morrell JB (1969) Practical Chemistry at the University of Edinburgh 1799-1843, AMBIX 26: 66-80.

21. Duckett SB, Garratt J, Lowe ND (1999) What do Chemistry graduates think? University Chem Educ 3: 1-7.

22. Lagowski JJ (2002) The role of the laboratory in chemical education 85 (1): 145.

23. Gunstone RF, Champagne AB (1990) Promoting conceptual change in the laboratory. In E. Hegarty-Hazel (Ed.). The student laboratory and the science curriculum London, UK.

24. Teixeira-Dias JJC, Pedrosa de Jesus MH, Neri de Souza F, Watts M (2005) Teaching for quality learning in Chemistry. Intl J Sci Educ 27: 1123 1137.

25. Kothari CR (2004) Quantitative Techniques ( $3^{\text {rd }}$ Edn). New Delhi, Vikas publishin House Pvt.Ltd. India.

\begin{tabular}{l} 
Your next submission with Juniper Publishers \\
will reach you the below assets \\
- Quality Editorial service \\
- Swift Peer Review \\
- Reprints availability \\
- E-prints Service \\
- Manuscript Podcast for convenient understanding \\
- Global attainment for your research \\
- Manuscript accessibility in different formats \\
( Pdf, E-pub, Full Text, Audio) \\
- Unceasing customer service \\
Track the below URL for one-step submission \\
https://juniperpublishers.com/online-submission.php \\
\hline
\end{tabular}

